This item was submitted to Loughborough's Research Repository by the author.

Items in Figshare are protected by copyright, with all rights reserved, unless otherwise indicated.

\title{
The empirical link between export dispersion and export performance: A contingency-based approach
}

PLEASE CITE THE PUBLISHED VERSION

https://doi.org/10.1016/j.ibusrev.2016.07.002

\section{PUBLISHER}

(C) Elsevier

\section{VERSION}

AM (Accepted Manuscript)

\section{PUBLISHER STATEMENT}

This work is made available according to the conditions of the Creative Commons Attribution-NonCommercialNoDerivatives 4.0 International (CC BY-NC-ND 4.0) licence. Full details of this licence are available at: https://creativecommons.org/licenses/by-nc-nd/4.0/

\section{LICENCE}

CC BY-NC-ND 4.0

\section{REPOSITORY RECORD}

Gnizy, Itzhak, John Cadogan, Joao Oliveira, and Asmat Nizam. 2016. "The Empirical Link Between Export Dispersion and Export Performance: A Contingency-based Approach”. Loughborough University. https://hdl.handle.net/2134/22540. 


\title{
The Empirical Link between Export Dispersion and Export Performance: A \\ Contingency-based Approach
}

\begin{abstract}
Practitioners and scholars point out that firms are increasingly dispersing their capabilities across organizational functions. However, it is not clear whether all forms of dispersion, of any function, result in the same consequences. This study initiates investigation into the link between the cross-functional dispersion of influence on export marketing decisions (export dispersion) and export performance. Drawing on data from a sample of 225 UK exporters, the findings support the argument that active participation of non-export functions in export-marketing decisions affects export success. However, those performance consequences are dependent on internal and external contingencies. Export dispersion is beneficial for export performance when the export customer environment is more turbulent and, simultaneously, the export technological environment is more stable and the firm has lower levels of export information sharing. In all other scenarios examined in this study, greater levels of concentration of export decision-making (i.e. lower levels of export dispersion) appear to be more beneficial for export performance. Our findings imply that the management of the firm's level of export dispersion is a complex task, whereby the degree of export dispersion pursued needs to match external environmental and internal firm factors.
\end{abstract}

Keywords: Export dispersion; Export cross-functional dispersion of influence; Export marketing; Export performance 


\section{INTRODUCTION}

The current study aims to address a critical research gap in the international marketing literature by examining the relationship between cross-functional dispersion of influence on export marketing activities (henceforth “export dispersion”) and export performance for the first time. The study also seeks to examine the role of external and internal firm contingencies in shaping the link between export dispersion and export performance.

Previous investigations pinpoint cross-functional dispersion of influence on marketing activities as critical for organizational performance because it enables firms to effectively respond to changes in customers’ needs and market conditions (Krohmer, Homburg and Workman 2002; Krush , Sohi, and Saini 2015). Nonetheless, there is lack of knowledge on of how cross-functional dispersion of influence on marketing activities affects business success in the export-specific context. This is unfortunate because it is widely recognized that relationships between business success and its predictors do not necessarily hold in the "export-specific" context of the firm due to the idiosyncratic nature of exporting (Boso, Cadogan, and Story 2012; Cadogan, Diamantopoulos, and Siguaw 2002). Thus, a core question remains regarding whether firms should engage all their business functions in export marketing decisions (i.e. enhance their export dispersion levels), or whether, alternatively, firms should concentrate export decision-making in one (or few) functional unit(s). The answer is not obvious: on one hand, greater dispersion levels may lead to better performance. On the other hand, lower dispersion levels may also bring benefits to firms (Krohmer et al. 2002). Therefore, the lack of information about the nature of export dispersion-export performance link constitutes a significant shortfall in knowledge.

Export dispersion decisions present the firm with key challenges, especially in terms of identifying environmental conditions and internal firm attributes that most or least 
appropriate for dispersion and shape its performance consequences. Prior research in noninternational business contexts indicates that the benefits of dispersion may depend on environmental contingency factors (e.g., market dynamism ; Krohmer et al. 2002), and so it is important to determine whether export environments, which are often complex and dynamic, shape the export dispersion-export performance relationship in a fashion similar to that uncovered in a domestic decision-making context. It is also important to know how to leverage export dispersion, which constitutes a feature pertaining to internal crossfunctional interactions, for export success. Critical interfunctional interactions are information sharing and goal alignment (Jaworski and Kohli 1993; Kahn 2001). Thus, we investigate those internal features that may operate to enhance the performance outcomes of export dispersion.

The remainder of this article is organized as follows. We present an overview of the pertinent literature and then move to discuss the theoretical framework, present our theoretical model, define key constructs, and develop the hypotheses. Subsequently, we describe the methodology used for data collection, the procedures adopted for measure validation and structural model testing, and outline our findings. Finally, we discuss the theoretical and practical implications, identify limitations, and suggest directions for future research. We then present a conclusion of the study.

\section{THEORETICAL BACKGROUND}

\section{Strategic Export Decision-making Process and Export Dispersion}

The firm's strategic decision-making process is a critical theme in strategy and international business research (e.g. Papadakis and Barwise, 2002; Papadakis, Lioukas, and Chambers, 1998). In this context, hierarchical decentralization, lateral communication, and political behavior are critical dimensions of the decision-making process in international firms (Dimitratos, Petrou, Plakoyiannaki, and Johnson 2011; Francioni, Musso, and Cioppi 2015). Hierarchical decentralization concerns the degree of dissemination of power within 
the organization in the process of decision-making. Lateral communication is the involvement level of all major business units in the decision-making process (Papadakis, Lioukas, and Chambers, 1998). Finally, political behavior is the influence of both internal actors and external parties on the decision-making process (Elbanna and Younies, 2008; Francioni, Musso, and Cioppi 2015). Issues concerning the strategic decision-making process have been covered by previous export performance investigations. Existing studies focus on different aspects of export decision-making, including decision-maker characteristics (Reid 1981), the degree to which export decisions are taken following a systematic approach (Nemkova, Souchon, Hughes, and Micevski 2015), or decisionmaking uncertainty (Raven, McCullough, and Tansuhaj 1994). However, with the exception of few studies (e.g. Cavusgil, Chan and Zhang 2003), research on hierarchical decentralization, lateral communication, and political behavior in export decision-making is missing in the literature. Cross-functional dispersion of influence on export marketing activities (i.e. export dispersion) is a key manifestation of the extent of which hierarchical decentralization, lateral communication, and political behaviour are adopted by firms in the export decision-making process. Our export dispersion core construct relates to the hierarchical decentralization dimension since higher export dispersion levels entail greater distribution of power on export decision across various business functions (i.e. they imply enhanced levels of hierarchical decentralization). Higher export dispersion levels also bring about the involvement of a greater number of major business functions (e.g. marketing/sales, manufacturing, and R\&D) in export decision-making, thus implying heightened lateral communication. Finally, higher export dispersion also entails greater levels of political behaviour because various business functions (i.e. internal actors) actively participate in and influence the export decision-making process. 


\section{Theoretical Foundation and Level of Analysis}

Our study is underpinned by contingency theory (Donaldson 2001), which contends that superior organizational performance is the result of a fit between organizational attributes and the context in which the firm operates (e.g. Venkatraman 1989). Specifically, we follow the perspective of fit-as-moderation (Venkatraman 1989), an approach that is increasingly used by export performance researchers (e.g. Cadogan, Kuivalainen, and Sundqvist, 2009; Lengler, Sousa, and Marques 2013; Navarro-García, Arenas-Gaitán, Rondán-Cataluña, and Rey-Moreno, 2015), which is rooted in the principle that no level of a particular organizational feature is universally superior. Rather, the impact of a certain predictor variable on performance depends on the value(s) of particular moderator variable(s). The level of fit between the predictor variable and the moderator variable(s) is a key determinant of performance. In the present study, we examine the link between export dispersion and export performance using export market dynamism, export information sharing and interfunctional goal alignment as moderators.

Researchers examining the determinants of export performance typically adopt either the export function or the export venture level of analysis (Oliveira, Cadogan, and Souchon 2012). Studies on export function level examine the overall export performance level achieved by the exporting entity (i.e. they focus on firm-wide export performance). Studies on venture level analyse an export venture within the firm with an export venture being defined as a single product or product line exported by a company to a specific foreign market (Cavusgil and Zou, 1994; Morgan, Kaleka, and Katsikeas 2004; Oliveira, Cadogan, and Souchon 2012). A fundamental principle of theory testing is that the level of analysis needs to match the level at which such a theory is developed (Klein, Dansereau and Hall 1994). Our study focuses the relationship between firm-wide cross-functional dispersion of influence on export marketing activities and firm-wide export performance 
levels and therefore we adopt the export function level of analysis.

\section{CONSTRUCT DEFINITIONS AND RESEARCH MODEL}

\section{Construct Definitions}

Export Dispersion. Following Krohmer et al. (2002) we conceptualize export dispersion as based on the distribution of power of different organizational functions over decisions in various export-marketing domains (e.g., pricing, new product development, customer satisfaction and service, and advertising). It is defined as "the degree of coherence with an identical influence distribution across all the functional groups” (Krohmer et al. 2002, p. 454). Importantly, as explained above export dispersion constitutes a manifestation of crucial dimensions of decision-making in international firms, namely hierarchical decentralization, lateral communication, and political behavior (c.f. Dimitratos et al. 2011; Francioni et al. 2015; Papadakis et al. 1998).

Export Performance. Business unit performance is described as the extent of the business unit’s financial success (Vorhies and Morgan 2005). Ample research underlines the relevance of financial performance as a proxy of export success (Wang and Lestari 2013). We focus on bottom-line performance, i.e., export profits. The underlying reasoning is that our conceptualization of export dispersion involves a number of export-marketing decisions (e.g. product development, distribution, communication, and pricing) that are known to influence export profits (Zou, Fang, and Zhao 2003).

Moderators. We examine export market dynamism (external factor), and export information sharing and interfunctional goal alignment (internal factors) as moderators of the export dispersion-export performance link. Export market dynamism refers to the frequency/rate of export market-related changes. We focus on market dynamism as a moderator since prior research in non-international context suggests that the benefits of dispersion are contingent upon the degree of market dynamism faced by firms (Krohmer et al. 2002). Furthermore, a growing body of the literature highlights the importance of 
market dynamism as a moderator of the relationship between export performance and its predictors (e.g. Cadogan, Kuivalainen, and Sundqvist 2009; Lisboa, Skarmeas and Lages 2013). We specifically examine two key dimensions of export market dynamism, namely customer and technological dynamism (Cadogan, Kuivalainen, and Sundqvist, 2009; Ito and Pucik 1993). As for the internal attributes, export dispersion constitutes a feature of firms' interfunctional interactions and reflects the degree of participation of different functional areas in export decision-making, a critical activity of international firms. Interfunctional interactions that have been studied in the literature include information sharing and goal alignment across business functions (Jaworski and Kohli 1993; Kahn 2001). We examine how those two factors act as contingencies of the dispersionperformance relationship in the export context. Export information sharing refers to the degree of which the firm disseminates export information (e.g., on competitors, customers, and market trends) within the firm and its availability to decision makers (e.g. Cadogan et al. 2012). Interfunctional goal alignment concerns the extent to which different business functions work together to attain common goals (e.g. Cadogan et al. 2005).

\section{Export Dispersion and Export Performance}

Existing research demonstrates positive implications of cross-functional interactions on performance (e.g. Luo, Slotegraaf, and Pan 2006). Cross-functional interactions are beneficial to firms in the context of decision-making since they can lead to enhanced coordination, integration and learning, spanning of organizational boundaries, reduced cycle times, and improved new product development (Krohmer et al. 2002). Specifically, different marketing activities require interactions of various functions and thus dispersion of the marketing decision influence (Krohmer et al. 2002).

Cross-functional dispersion of marketing is linked to reduced conflict and increased communication with other functions (Moorman and Rust 1999). In the export context, when multiple functions participate in the export decision-making process, they are more 
likely to exhibit higher commitment to the resulting decisions, thus enhancing the chances of their successful implementation. In addition, the participation of multiple business functions in the export decision-making process allows multiple points of view to be considered and leads to the challenge of assumptions due to integrated knowledge and skills (Moorman and Rust 1999). Specifically, the integrated experiences and expertise of employees from different functions and their all-inclusive perspectives facilitate the firm's effectiveness in responding to changes in export environments. Furthermore, crossfunctional dispersion of export decisions leads to a reduction in cycle times and enhances the efficient use of resources since, for example, there is a lesser need for repetitive discussions (Engelen 2011). Therefore, export dispersion is likely to have a positive impact on export-related effectiveness and efficiency, both of which contribute to enhance the firm’s export profits.

Export dispersion can be seen as a risk management tool in the export decisionmaking process. While managing uncertainty is a key objective for international firms (Ghoshal 1987), behavioral uncertainty is a critical type of risk that these firms face (Miller 1992). For example, managers at various levels of the organization are often faced with incentives to behave opportunistically to enhance their personal welfare at the expense of the firm's success (Jansen and Mecklin, 1976; Miller 1982). However, greater participation of individuals from multiple functional areas in export decision-making (i.e. greater levels of export dispersion) can reduce behavioral uncertainty as it implies less reliance on a small number of decision-makers. As such, export dispersion can contribute to reduced behavioral uncertainty with regard to the firm's export activities.

Conversely, lower levels of dispersion (i.e. greater levels of concentration of decision-making in one/few functions) may result in less effective decisions that are based on 'territorial viewpoints', reflect a narrower worldview and lack a superordinate attention 
(Cadogan et al. 2005). Furthermore, the concentration of the responsibility for export marketing decisions and activities within one group of specialists in the firm is concomitant with problems such as reduced information sharing among functions, and inter-functional conflict (Moorman and Rust 1999). In addition, lower levels of export dispersion can lead to higher levels of behavioral uncertainty, as they will likely imply greater reliance on a smaller number of decision-makers for export decisions, thereby increasing the chances of opportunistic behavior. Therefore, we hypothesize that:

$H_{1}$ : The greater the firm's degree of export dispersion the greater the firm's export performance.

\section{Moderating Effects of Export Dispersion-Performance Link}

Environmental dynamism moderates the link between export decision-making factors and export performance (Glenn Richey and Myers 2001). Krohmer et al. (2002) find that market dynamism negatively moderates the relationship between cross-functional dispersion of influence on marketing activities and performance. The same may also apply in the export context. Active participation of multiple business functions in the export decision-making process (i.e. greater levels of export dispersion) are likely to be timeconsuming, hence reducing the firm's ability to adapt to changes in the export environment in a timely fashion. Greater levels of export market dynamism require the firm to be quicker to respond to environmental change (Rose and Shoham 2002). Accordingly, it is likely that export dispersion will become less beneficial for performance as export market dynamism rises. Thus, we hypothesize that:

$\mathrm{H}_{2}$ : Export market dynamism negatively moderates the relationship between export dispersion and export performance.

Cadogan et al. (2005) identify exporting interfunctional interactions as critical factors in terms of determining the success of export marketing decisions and strategy. Specifically, they argue that it is important for communication and information sharing to 
take place so that functional areas other than exporting can understand the context that exporting decisions are made in. Communication and information sharing will be particularly relevant when those functions are more involved in formulating those decisions. The need for information sharing is, therefore greater under conditions of high export dispersion. Hence, we hypothesize that:

$\mathrm{H}_{3}$ : Export information sharing positively moderates the relationship between export dispersion and export performance.

Furthermore, it is also widely recognized that alignment of departmental goals is vital in order to eliminate conflict and facilitate effective decision-making. Research indicates that lack of alignment between decision-making partners is dysfunctional for decision-making, and can lead to opportunistic behavior (such as overstating one’s own department's needs), hostility, and distortion of information. These activities are most likely to negatively influence export success when multiple departments are involved in export decision making. However, goal alignment allows for healthy interactions and challenges of assumptions (Menon, Bharadwaj, and Howell 1996), and enables the firm to reap the benefits of multiple worldviews brought by higher levels of dispersion.

Accordingly, we hypothesize that:

$\mathrm{H}_{4}$ : Interfunctional goal alignment positively moderates the relationship between export dispersion and export performance.

\section{Summary}

Our conceptual model is depicted in Figure 1 and summarizes the relationships between the constructs. Cross-functional dispersion of influence on export marketing activities has a positive impact on export performance. The dispersion-performance link is moderated negatively by export market dynamism, and positively by export information sharing and interfunctional goal alignment. Control variables to monitor for potential confounds are also included in the model. The literature suggests firms' export resources 
and export experience as critical export performance predictors (Morgan, Kaleka, and Katsikeas 2004). Hence, we include those predictors as controls.

[Insert Figure 1 about here]

\section{RESEARCH METHODOLOGY}

We used data from a cross-sectional mail survey of exporting UK companies for the model testing. We adopted the key informant approach, which is in accordance with methodologies deployed in current export performance studies (e.g. Zeriti et al. 2014).

\section{Sampling and Data Collection}

We drew a random sample of 1679 exporting firms with 50 or more employees from the Kompass UK database. The choice to focus only on such firms is because our internal firm moderators correspond to inter-functional phenomena. We therefore selected firms with a "large enough" number of employees (Cadogan et al. 2001) to be able to capture such constructs in a precise manner. We pre-notified the selected firms by telephone to confirm whether the contact details we had were accurate, to identify an appropriate key respondent, and to request participation. Telephone pre-notification led to the identification of 918 managers who agreed, in principle, to participate and met key informant knowledgeability criteria. We received 277 responses. The discrepancy between the number of questionnaires sent after telephone pre-notification (918) and the number of responses received (277) is common in export performance studies (e.g. Costa, Lages and Hortinha 2015; Nemkova, Souchon, Hughes and Micevski 2015; Zeriti et al. 2014), and probably reflects the fact that a proportion of respondents agreed to receive the survey without real intention to complete it. Subsequent screening revealed that 23 out of the 277 received responses corresponded to companies that were ineligible to participate, thereby reducing the number of eligible firms from 918 to 895 . Furthermore, of the 277 responses obtained, 11 were discarded because of missing data, 18 indicated the respondent's refusal to participate. Our final sample consisted therefore of 225 usable responses (i.e. 277-23- 
11-18), which corresponded to a response rate of $25.1 \%$ (i.e. $(225 / 918)$ x 100). Our response rate is in accordance with response rates reported by other export performance investigations (Sousa et al. 2008). A battery of t-tests that compared early and late respondents with regard to our study's constructs revealed no significant differences at the 5\% level, which indicates that non-response bias is not likely to be a problem in this study (Armstrong and Overton 1977).

\section{Sample Profile}

The average firm in the sample had 350 employees, had been exporting for 36 years, exported to 28 countries, and generated 39\% of its sales from exporting. In terms of scope of export operations, 95\% of the firms exported to the European Union (EU), 70\% to North America, 69\% to Asia, 57\% to Eastern Europe, 63\% to the Middle East, 54\% to Australia/New Zealand, 49\% to Africa, and 37\% to South/Central America. Firms operated in a wide variety of industries such as food \& beverages, chemical, cosmetics, pharmaceuticals, defense, aerospace, biotechnology, and automotive. Respondents occupied top management positions such as CEOs, chairpersons, sales directors, export managers, and export executives.

\section{Measurement Scales}

We took the measures of the constructs essentially from previous studies (Appendix). The scale for export dispersion was adapted from Krohmer et al.’s (2002) measure of cross-functional dispersion of influence on marketing activities. The measure was constructed by first assessing the influence of five functional groups (export function, marketing/sales, finance/accounting, manufacturing, and R\&D) over eight strategic decisions concerning export marketing activities, namely (1) pricing; (2) new product development; (3) customer satisfaction improvement; (4) customer service and support; (5) customer satisfaction measurement; (6) distribution strategy; (7) expansion into new markets, and; (8) market advertising decisions. 100-point constant-sum scales were used. 
The list of strategic decisions adopted is consistent with prior research on dispersion of marketing activities (Krohmer et al. 2002).

We then computed the standard deviations of each of those influence scores. In the extreme case of identical influence across all functional groups regarding a certain decision, the standard deviation of the corresponding influence score equals zero, indicating maximum dispersion of influence across functional areas regarding the decision. We then averaged the eight standard deviations and multiplied the resulting figure by -1 . The resulting score was then adjusted to create our final dispersion index, where 0 and 44.72 correspond to minimum and maximum of export dispersion, respectively.

We measured export performance using an adaptation of Cadogan et al.’s (2005) export profit performance scale. Specifically, using a 10-point scale (1 = "very dissatisfied"; 10 = "very satisfied"), we asked managers to rate their satisfaction with the firm's export profitability over the previous three years, as well as the profitability of their firm's export operations during the previous financial year.

We measured two sources of export market dynamism, namely export customer dynamism and export technological dynamism. We assessed these constructs via two-item scales adapted from Jaworski and Kohli’s (1993) 'market turbulence’ and 'technological turbulence’ measures, respectively. We used the firm's degree of export market intelligence dissemination (Cadogan et al. 2001) as a proxy for firm’s level of export information sharing. We assessed interfunctional goal alignment via an adaptation of Cadogan et al.’s (1999) ‘coordination mechanism’ scale. We used the logarithmic transformation of the firm's number of employees directly involved with export matters as a proxy for export resources (Thirkell and Dau 1998). We assessed export experience via the logarithmic transformation of the number of years the firm had been involved in export operations (Bijmolt and Zwart 1994). 


\section{Reliability and Validity}

We assessed measurement scale reliability and validity via confirmatory factor analysis (CFA). We entered all reflective items simultaneously into a CFA using LISREL 8.80 (Jöreskog and Sörbom 2007). We adopted the maximum likelihood estimation procedure. Model fit was assessed via the conventional chi-square statistic, as well as other key fit heuristics (Diamantopoulos and Siguaw 2009). Table 1 shows the measurement model statistics as well as the correlations among the constructs.

[Insert Table 1 about here]

As depicted in Table 1, key fit indicators of the measurement model were within recommended thresholds suggesting good fit with the data. All average variances extracted (AVE) surpassed the squares of the correlations between latent constructs providing support for the discriminant validity of the measures. In addition, composite reliabilities were large (>.60), as were AVEs ( $\geq .50)$. Hence, the measures exhibited sufficient convergent and discriminant validity for model testing.

\section{Common Method Variance Assessment}

Following established guidelines (Chang, Witteloostuijn, and Eden 2010), we implemented a number of research design-related procedures aimed at minimizing the potential for common method variance (CMV), such as varying the length of Likert-type measures used to assess different constructs, using reverse coding, and adopting objective measurement instruments. To further rule-out CMV, we ran Harman's one factor test in CFA. The test yielded a poor model fit (chi-square $=783.15, p=.00$, d.f. $=104$, RMSEA $=.17, \mathrm{NNFI}=.42 \mathrm{CFI}=.50$ ) suggesting that no single factor is responsible for most of the variance in the measures. Furthermore, we ran Lindell and Whitney’s (2001) method marker test. We adopted the marker variable "how successful are your customers in your key UK (domestic) markets in negotiating lower prices from you?”, which is theoretically 
not linked to any of our model's constructs. We did not detect any significant correlation ($.09 \leq \mathrm{r} \leq .15$ ) suggesting that CMV is not likely to be an issue. Lastly, our model contains a number of relationships that are not straightforward (e.g. moderating effects). As such, it would have been arduous (if not impossible) for respondents to form mental models and predict the relationships being examined. We therefore concluded that CMV was not likely to be a problem in this research.

ANALYSES and FINDINGS

\section{Descriptive Results}

Table 2 shows the influence scores of the different functional groups on the different export marketing decision activities used to compute our export dispersion measure. The scores provide a number of insights. First, the export function exhibits relatively high scores across all eight decisions. Therefore, the export function is in a position to communicate its value relevance across the overall spectrum of export decisions. Second, there are no export marketing decisions in which cross-functional dispersion is either maximal (i.e. in which influence is distributed equally across all the functional groups) or minimal (i.e. in which influence is completely concentrated in one functional group). This indicates that there is no decision taken completely without input from the export function. Third, major functional areas within the firm have some degree of influence in each of the export decisions examined. It can be concluded, hence, that export decisions tend to span functional boundaries, being influenced both by export- and non-export dedicated functional areas.

\section{[Insert Table 2 about here]}

\section{Structural Model Estimation}

Following established procedure (Song et al. 2005) we started by mean centering the raw scores of predictor variables. Such technique contributes to diminish potential problems of multicollinearity associated with the inclusion of interaction terms in the 
model (Aiken and West 1991). We used traditional product-term analysis to test for moderation effects (Ping 1995). Our moderation hypotheses argued that the export dispersion-performance link is moderated by export market dynamism $\left(\mathrm{H}_{2}\right)$, by export information sharing $\left(\mathrm{H}_{3}\right)$, and by interfunctional goal alignment $\left(\mathrm{H}_{4}\right)$. Thus, we computed the required multiplicative terms and entered them into the model equation. To ensure model parsimony we entered direct effects (namely, of export dispersion, export customer dynamism, export technological dynamism, export information sharing, and interfunctional goal alignment) as controls (Aiken and West 1991). We also included export resources and export experience as controls.

We used single indicants to estimate interactions between latent constructs (Ping 1995). This procedure is recommended to lessen model complexity (Jaccard and Wan 1996). We computed single indicants for export market dynamism (both for customer dynamism and for technological dynamism), for export information sharing, and for interfunctional goal alignment via averaging the corresponding measurement items. Export resources and export experience were already measured via single-item scales. Export performance was modeled as a first-order latent variable of its two items. We set the error variances of each single indicant latent variable at $\left[(1-\alpha) x \sigma^{2}\right]$, where $\alpha$ corresponds to the construct reliability and $\sigma$ to the standard deviation of the single indicant (Jöreskog and Sörbom, 1993).

In order to set the loadings and error variances of the interaction terms we followed guidelines established by Ping (1995). Specifically, we ran a CFA model in which the dependent latent variable and all the latent variables involved in the interactions (namely, export dispersion, export customer dynamism, export technological dynamism, export information sharing, and interfunctional goal alignment were included: however, in this instance, the latter variables contained only a single indicant, since this greatly simplifies 
the estimation procedure. The loadings of the single indicants were set at 1 and the error variances at [(1 - $\alpha) \times$ б2] (Jöreskog and Sörbom, 1993). We recorded the standardized estimates from this CFA and plugged these values into the equations provided by Ping (1995) to produce estimates of the loadings for the interaction terms' loadings and error variances.

We then ran two structural models in LISREL 8.80 (Jöreskog and Sörbom 2007), namely a constrained model and an unconstrained model. In the constrained model we permitted only the direct effects to be estimated freely and fixed interaction terms at zero. In the unconstrained model (Model 2, Table 1) all effects were estimated freely. We estimated the following equation for both models.

Export profit performance $=\gamma 1$ export dispersion $+\gamma 2$ export dispersion $x$ export customer dynamism $+V 3$ export dispersion $x$ export technological dynamism + V4 export dispersion $x$ export information sharing $+\gamma 5$ export dispersion $x$ interfunctional goal alignment $+\gamma 6$ export customer dynamism $+V 7$ export technological dynamism $+\gamma 8$ export information sharing $+\gamma 9$ interfunctional goal alignment + V10 export resources $+\gamma 11$ export experience

As outlined above, in the constrained model we allowed only the direct effects to be estimated freely and fixed interaction terms at zero. Accordingly, in the constrained model we set $\mathrm{\gamma} 2, \mathrm{\gamma} 3, \mathrm{\gamma} 4$, and $\mathrm{\gamma} 5$ equal to zero and allowed the package to estimate all the remaining coefficients. In the unconstrained model, all coefficients of equation (1) were estimated freely. As shown in Table 1, the reduction in chi-square which resulted from moving from the constrained to the unconstrained model was statistically significant ( $\Delta \chi 2$ $($ d.f. $)=14.78(4), p<.05)$. The unconstrained model also explained approximately $47 \%$ 
more variance in the dependent variable relative to the constrained model (the R-square statistics of the constrained and unconstrained models were $17 \%$ and $25 \%$, respectively). Hence, the unconstrained model fitted better the data than the constrained model. In addition, the chi-square statistic of the unconstrained model was non-significant $(\chi 2=$ 10.57, $p>.05$ ), and its key fit indicators were within recommended thresholds (RMSEA = $.02 ; \mathrm{CFI}=1.00 ; \mathrm{NFI}=.97 ; \mathrm{NNFI}=.97)$, suggesting an excellent fit with the data (c.f. Diamantopoulos and Siguaw 2009). Thus, we decided that the unconstrained model was suitable for purposes of hypothesis testing.

\section{Hypotheses Testing}

Table 3 shows the standardized coefficient estimates for the constrained model and for the unconstrained model, as well as the corresponding t-values. Because our hypotheses are directional (i.e., they anticipate positive/negative direct/moderating effects) we used one-tailed tests to assess the magnitude and significance level of the coefficient estimates (Diamantopoulos and Schlegelmilch 2000). In one-tailed t-tests, t-values are deemed significant at the $5 \%$ and $1 \%$ levels if their absolute values surpass1.65 and 2.33, respectively. As mentioned above, the estimates associated with the unconstrained model are the ones pertinent for hypothesis testing. Inspection of Table 3 reveals that the coefficient linked to export dispersion is not significant $(\mathrm{Y} 1=-.05, \mathrm{t}=-.66, p>.05)$, indicating the lack of a “main” impact of export dispersion on export performance. Nonetheless, the coefficients associated with three out of the four product terms corresponding to moderating effects on the export dispersion-export performance link (namely, $\mathrm{V} 2, \mathrm{Y3}$, and $\mathrm{\gamma} 4$ ) were significant (as discussed below). Since $\mathrm{H}_{1}$ is nested within such product terms, the latter will be the "final verdict" regarding of the effect of export dispersion on export performance. (c.f. Kam and Franzese 2007). We discuss the effect of export performance under high/low values of the moderators in the Post Hoc Analyses 
section. The interaction between export dispersion and export market dynamism is significant and positive for customer dynamism $(\mathrm{Y} 2=.16, \mathrm{t}=2.13, p<.05)$, and significant and negative for technological dynamism $\left(\mathrm{Y}^{3}=-.16, \mathrm{t}=-2.22, p<.05\right) . \mathrm{H}_{2}$ is hence partially supported. The interaction between export dispersion and export information sharing is significant and negative $(\mathrm{\gamma} 4=-.16, \mathrm{t}=-2.11, p<.05) . \mathrm{H}_{3}$ is, thus, rejected. Finally, the interaction between export dispersion and interfunctional goal alignment is not significant ( $\mathrm{Y} 5=.05, \mathrm{t}=.72, p>.05)$. Hence, $\mathrm{H}_{4}$ is not supported. As expected, the path relating to export resources (our first control variable) is positive and significant ( $\mathrm{Y} 10$ $=.27, \mathrm{t}=2.83, p<.01)$. Contrarily to what we anticipated, the path associated to export experience (our second control variable) is significant and negative $(\mathrm{Y} 11=-.16, \mathrm{t}=-1.77$, $p<.05)$

\section{[Insert Table 3 about here]}

\section{Post Hoc Analyses}

We ran a number of post-hoc analyses to shed additional light on our main findings. First, we conducted a deeper examination of the unsupported “main" effect of export dispersion on export performance $\left(\mathrm{H}_{1}\right)$. One could argue that the relationship between export dispersion and performance might be non-linear. Higher levels of dispersion imply the participation of many employees from various functions in the export decision-making, possibly leading to situations where "too many cooks spoil the broth”. Such employees have different perspectives and interests, they lack export-marketing competences, and exporting tasks may not be a priority for them. Such factors may lead to unsophisticated and ineffective compromises in the export decision-making process and, thus to lower quality decisions. In addition, higher levels of dispersion may imply excessive coordination and managerial effort to come to export decisions, which can be costly and time-consuming. As a result, the export dispersion-performance relationship could potentially become less positive under greater levels of dispersion, indicating a non- 
linear relationship. To test this argument we ran a parsimonious model in which export performance is predicted by dispersion and dispersion-squared. To assure comparability with our main model, we included the control variables used in the main model (cf. Aiken and West 1991). Both dispersion and dispersion-squared yielded non-significant coefficients with export performance indicating that there is no "main" effect of export dispersion (neither linear nor non-linear) on export performance.

Second, we further explored the effects of the moderating variables that came significant. Specifically, we analyzed the export dispersion-export performance relationship link under low and high values of export customer dynamism, export technological dynamism, and export information sharing (cf. Aiken an West 1991). Results appear in Figure 2.

\section{[Insert Figure 2 about here]}

Inspection of Figure 2 reveals that export dispersion is only beneficial for export performance when firms' export customer environments are dynamic and, at the same time, both export technological dynamism and export information sharing are low (this situation is depicted by the full line in quadrant B of Figure 2). In all the other cases, export dispersion appears to be detrimental to export performance.

\section{DISCUSSION}

\section{Theoretical Implications}

This study set out to examine the complex organizational and export-marketing phenomenon of cross-functional dispersion of influence as well as its implications on export performance. While other scholars have studied the concept of dispersion, our study focuses on export performance outcomes of export dispersion, a topic that has not been addressed in prior research. Furthermore, we build on existing literature that examines the external environment as a moderator of the dispersion-performance link (e.g., Krohmer et al. 2002) to examine, for the first time, the role of key internal factors as contingencies of 
such relationship.

Our results differ from the ones of Krohmer et al. (2002) who found positive direct effect of marketing dispersion on performance. Our findings seem to support the notion that has been put forward in the literature (e.g., Cadogan, Diamantopoulos, and Siguaw 2002) that the link between overall business success and its predictors does not necessarily hold automatically in the idiosyncratic context of firms' export activities. Interestingly, we found that the role of export market dynamism on the relationship between export dispersion and export performance is mixed. On the one hand, export customer dynamism positively moderates the export dispersion-export performance link. Hence, when export customers' needs and wants change rapidly, there is a greater need for export dispersion as a mechanism for reduced conflict and enhanced coordination levels among business functions (Moorman and Rust 1999). In turn, diminished conflict and greater coordination are critical factors for the firm to cope successfully with fast-changing customer environments. On the other hand, technological dynamism negatively moderates the export dispersion-export performance link. Such a result may be explained by the fact that greater levels of export dispersion are likely to imply the participation of less technologically knowledgeable managers in the export decision-making process. This is likely to slow down the decision-making (Krohmer et al. 2002) and, as such reduce the firm's ability to adapt to technological changes in a timely fashion, the latter being a critical ingredient for success in technologically turbulent export environments.

Surprisingly, we found that export information sharing negatively moderates the export dispersion-export performance link. A potential explanation could be that the combination of greater degrees of export dispersion with higher export information sharing levels generates a problem of information overload, as people from multiple business functions will need to filter and assimilate greater amounts of export-related information. 
This may slow down the export decision-making process, reducing the firm's ability to adapt to changes in the export environment. As such, the benefits of export dispersion may be reduced.

Furthermore, we found no empirical support for a positive moderating effect of interfunctional goal alignment on the export dispersion-export performance relationship. There may be, thus, additional variables that were not included in this research which affect the role of interfunctional goal alignment in moderating the export dispersion-export performance link. The investigation of such variables constitutes a potentially fruitful future research direction. In terms of the control variables, the strong and positive coefficient we found for the effect of export resources on export performance further validates previous findings (e.g. Thirkell and Dau 1998). Against our expectations, we did not detect a positive impact of export experience on export performance. It may be that, although greater levels of export experience make the firm wiser in its export activities, they also entail higher levels of rigidity, rendering the firm less capable of adapting to changes in export environments.

\section{Managerial Implications}

Our results suggest that export dispersion is a key predictor of export performance. Nonetheless, the degree of usefulness of export dispersion on export performance is contingent upon the degree of export market dynamism and on the firm's level of export information sharing. Specifically, as illustrated in Figure 2, export dispersion has a positive impact on export performance when export customer dynamism is high and, simultaneously, the firm operates with more stable technology(s) and displays lower levels of export information sharing. Hence, while greater export dispersion levels can bring benefits to the firm in the form of increased effectiveness and/or efficiency, and of reduction in behavioral risk in the decision-making process, such factors will only produce 
positive returns in the above-described scenario. Under more stable export customer environments and/or when the firm exhibits greater levels of information sharing, it may be preferable to pursue greater levels of concentration in the export decision-making process.

Thus, it is critical that managers assess the degree of customer and technological dynamism in their firms' export markets when deciding on how much export dispersion to pursue. In addition, as shown in Figure 2, the usefulness of greater levels of export dispersion for enhancing export performance is hindered by export information sharing regardless of the levels of export customer/technological dynamism. Hence, managers should not combine higher levels of export dispersion with investments in export information. We also recommend that managers evaluate their firms' levels of export information sharing when deciding on how much export dispersion to undertake. It is critical to emphasize that the decision of how much dispersion to undertake in the export decision-making process also needs to account for key industry- and market-related factors not examined in the present study. Examples of such factors include the specific industry(s) in which the firm operates, the percentage of the firm's export revenue derived from Business-to-Business (B2B) and from Business-to-Consumer (B2C) activities, or cultural differences faced by the firm across its foreign markets.

\section{Limitations and Further Research Directions}

First, the dispersion of marketing activities across multiple business functions has been associated with marketing’s influence within the firm (Krush et al. 2015). Accordingly, a potentially fruitful research avenue could be the examination of the relationship between firms' levels of export dispersion and the degree of influence of the marketing function within the firm, as well as the interplay between those two variables in shaping export performance.

Second, the literature does not provide a comprehensive list of the critical marketing decisions undertaken by firms. Our measure of export dispersion was adapted 
from Krohmer et al.’s (2002) scale of cross-functional dispersion of influence on marketing activities and comprises the decisions that are most commonly examined in studies that consider issues relating to the dispersion of decision-making within the firm with regard to marketing activities (Homburg et al., 2015; Verhoef and Leeflang 2009). Thus, while our measure is consistent with prior research, it is far from being exhaustive, and future studies may incorporate other decisions in the context of their international activities when assessing export dispersion. For example, two key decisions are international market selection- and entry mode-decisions.

Third, export dispersion can contribute to diminished behavioral uncertainty with regard to the firm's export activities, potentially acting as a risk management tool. Nonetheless, we did not include risk explicit related-variables (e.g., degree of behavioral uncertainty) in our model. Such a limitation can potentially explain our finding on the lack of a "main” effect of export dispersion on export performance. One may expect behavioral uncertainty to act as a mediator of the export dispersion-export performance relationship. The inclusion of risk specifications in models that examine this relationship may be a fruitful research avenue.

Fourth, export information sharing was found to negatively moderate the export dispersion-export performance relationship. Thus, there may be other variables not included in the present study that affect the role of export information sharing as a moderator of the aforementioned link. The investigation of such factors constitutes, hence, an interesting research direction. There may be also additional internal firm factors that moderate the export dispersion-export performance relationship which were not included in the present study. For example, greater export dispersion levels foster the involvement of people with various different backgrounds (e.g. marketing, engineering, finance). As such, one could argue that certain organizational systems (e.g., human resources-related 
systems) may leverage the benefits of export dispersion and positively moderate the export dispersion-export performance link.

In addition, the magnitude of the benefits brought by export dispersion may be country-specific. For instance, greater export dispersion levels can lead to the challenging of assumptions. While this may be seen as positive and constructive in some countries, in others it may be perceived as an aggressive behavior that defies authority. The link between export dispersion and export performance may, hence, vary across different countries. The replication of the present study in settings other than UK may cast light on context-related variables that may affect the export dispersion-export performance relationship. Relatedly, the present study does not include a number of industry- and market-related variables, which may affect export dispersion and/or its relationship with export performance. Examples of such factors are the particular industry(s) in which the firm operates, the percentage of the firm's export sales revenue accrued by B2B and B2C activities, or the magnitude of cultural differences faced by the firm across its export markets. The inclusion of such variables in future research may be a potentially fruitful research avenue.

\section{CONCLUSIONS}

The present study puts forward the issue of active participation of multiple business functions in export marketing decisions and points out its levels as a critical predictor of export performance. The management of export dispersion is an intricate task because its effect on export success is tied to multiple contingencies. Greater export dispersion levels are advantageous when the export customer environment is more turbulent and, concurrently, the export technological environment is more stable and the firm employs lesser levels of export information sharing. In all other situations examined, higher levels of concentration of export decision-making (i.e. lower levels of export dispersion) should be adopted. It is hence crucial that firms evaluate the degree of customer and technological 
dynamism in their export markets, as well as their degree of export information sharing when deciding on how much export dispersion to pursue. To the authors' knowledge, this is the first study that examines the link between cross-functional dispersion of influence on marketing activities and performance in the particular context of export activities. Export dispersion management is likely to increase firms' awareness and interest in conditions and behaviors that can enhance or inhibit performance. 


\section{REFERENCES}

Aiken, L., \& West, S. G. (1991). Multiple regression: testing and interpreting interactions. Thousand Oaks, CA: Sage Publications.

Armstrong, J. S., \& Overton, T. S. (1977). Estimating nonresponse bias in mail surveys. Journal of Marketing Research, 14(3), 396-402.

Bijmolt, T. H., \& Zwart, P. S. (1994). The impact of internal factors on the export success of Dutch small and medium-sized firms. Journal of Small Business Management, 32(2), 69.

Boso, N., Cadogan, J. W., \& Story, V. M. (2012). Complementary effect of entrepreneurial and market orientations on export new product success under differing levels of competitive intensity and financial capital. International Business Review, 21(4), 667-681.

Cadogan, J. W., Diamantopoulos, A., \& De Mortanges, C. P. (1999). A measure of export market orientation: scale development and cross-cultural validation. Journal of International Business Studies, 30(4), 689-707.

Cadogan, J. W., Diamantopoulos, A., \& Siguaw, J. A. (2002). Export market-oriented activities: their antecedents and performance consequences. Journal of International Business Studies, 33(3), 615-626.

Cadogan, J. W., Kuivalainen, O., \& Sundqvist, S. (2009). Export market-oriented behavior and export performance: quadratic and moderating effects under differing degrees of market dynamism and internationalization. Journal of International Marketing, 17(4), 71-89.

Cadogan, J. W., Paul, N. J., Salminen, R. T., Puumalainen, K., \& Sundqvist, S. (2001). Key antecedents to "export” market-oriented behaviors: a cross-national empirical examination. International Journal of Research in Marketing, 18(3), 261-282.

Cadogan, J. W., Sundqvist, S., Puumalainen, K., \& Salminen, R. T. (2012). Strategic flexibilities and export performance: The moderating roles of export marketoriented behavior and the export environment. European Journal of Marketing, 46(10), 1418-1452.

Cadogan, J. W., Sundqvist, S., Salminen, R. T., \& Puumalainen, K. (2005). Export marketing, interfunctional interactions, and performance consequences. Journal of the Academy of Marketing Science, 33(4), 520-535. 
Cavusgil, S. T., Chan, K., \& Zhang, C. (2003). Strategic orientations in export pricing: a clustering approach to create firm taxonomies. Journal of International Marketing, 11(1), 47-72.

Cavusgil, S. T., \& Zou, S. (1994). Marketing strategy-performance relationship: an investigation of the empirical link in export market ventures. Journal of Marketing, 58(1),1-21.

Costa, C., Lages, L. F., \& Hortinha, P. (2015). The bright and dark side of CSR in export markets: Its impact on innovation and performance. International Business Review, 24(5), 749-757.

Chang, S. J., Van Witteloostuijn, A., \& Eden, L. (2010). From the editors: Common method variance in international business research. Journal of International Business Studies, 41(2), 178-184.

Diamantopoulos, A., \& Schlegelmilch, B. B. (2000). Taking the fear out of data analysis. Bournemouth: Thomson Learning.

Diamantopoulos, A., \& Siguaw, J. (2009). Introducing LISREL. London: Sage.

Dimitratos, P., Petrou, A., Plakoyiannaki, E., \& Johnson, J. E. (2011). Strategic decisionmaking processes in internationalization: does national culture of the focal firm matter?. Journal of World Business, 46(2), 194-204.

Donaldson, L. (2001). The contingency theory of organizations. London: Sage.

Elbanna, S., \& Younies, H. (2008). The relationships between the characteristics of the strategy process: evidence from Egypt. Management Decision, 46(4), 626-639.

Engelen, A. (2011). Which department should have more influence on organization-level decisions? A strategy-dependent analysis. Journal of Strategic Marketing, 19(3), 229-254.

Francioni, B., Musso, F., \& Cioppi, M. (2015). Decision-maker characteristics and international decisions for SMEs. Management Decision, 53(10), 2226-2249.

Ghoshal, S. (1987). Global strategy: An organizing framework. Strategic management Journal, 8(5), 425-440.

Glenn Richey, R., \& Myers, M. B. (2001). An investigation of market information use in export channel decisions-antecedents and outcomes. International Journal of Physical Distribution \& Logistics Management, 31(5), 334-353.

Homburg, C., Vomberg, A., Enke, M., \& Grimm, P. H. (2015). The loss of the marketing department's influence: is it really happening? And why worry? Journal of the Academy of Marketing Science, 43(1), 1-13. 
Ito, K., \& Pucik, V. (1993). R\&D spending, domestic competition, and export performance of Japanese manufacturing firms. Strategic Management Journal, 14(1), 61-75.

Jaccard, J., \& Wan. C. K. (1996). LISREL approaches to interaction effects in multiple regression. Thousand Oaks, CA: Sage Publications.

Jaworski, B. J., \& Kohli, A. K. (1993). Market orientation: Antecedents and Consequences. Journal of Marketing, 57(3), 53-70.

Jensen, M. C., \& Meckling, W. H. (1976). Theory of the firm: Managerial behavior, agency costs and ownership structure. Journal of Financial Economics, 3(4), 305360.

Jöreskog, K., \& Sörbom, D. (1993), LISREL 8: structural equation modeling with the SIMPLIS command language. NJ: Scientific Software International.

Jöreskog, K., \& Sörbom, D. (2007). LISREL 8.80. Lincolnwood, IL: Scientific Software International, Inc.

Kahn, K. B. (2001). Market orientation, interdepartmental integration, and product development performance. Journal of Product Innovation Management, 18(5), 314-323.

Kam, C. K., \& Franzese Jr., R. J. (2007). Modeling and interpreting interaction hypotheses in regression analysis. MI: The University of Michigan Press.

Klein, K. J., Dansereau, F., \& Hall, R. J. (1994). Levels issues in theory development, data collection, and analysis. Academy of Management Review, 19(2), 195-229.

Krohmer, H., Homburg, C., \& Workman, J.P. (2002). Should marketing be crossfunctional? Conceptual development and international empirical evidence. Journal of Business Research, 55(6), 451-65.

Krush, M. T., Sohi, R. S., \& Saini, A. (2015). Dispersion of marketing capabilities: impact on marketing's influence and business unit outcomes. Journal of the Academy Marketing Science, 43(1), 32-51.

Lengler, J. F., Sousa, C. M., \& Marques, C. (2013). Exploring the linear and quadratic effects of customer and competitor orientation on export performance. International Marketing Review, 30(5), 440-468.

Lindell, M. K., \& Whitney, D. J. (2001). Accounting for common method variance in cross-sectional research designs. Journal of Applied Psychology, 86(1), 114-121.

Lisboa, A., Skarmeas, D., \& Lages, C. (2013). Export market exploitation and exploration and performance: Linear, moderated, complementary and non-linear effects. International Marketing Review, 30(3), 211-230. 
Luo, X., Slotegraaf, R. J., \& Pan, X. (2006). Cross-functional “coopetition”: The simultaneous role of cooperation and competition within firms. Journal of Marketing, 70(2), 67-80.

Menon, A., Bharadwaj, S. G., \& Howell, R. (1996). The quality and effectiveness of marketing strategy: effects of functional and dysfunctional conflict in intraorganizational relationships. Journal of the Academy of Marketing Science, 24(4), 299-313.

Miller, K. D. (1992). A framework for integrated risk management in international business. Journal of International Business Studies, 23(2), 311-331.

Moorman, C., \& Rust, R. T. (1999). The role of marketing. Journal of Marketing, 63(4), 180-197.

Morgan, N. A., Kaleka, A., \& Katsikeas, C. S. (2004). Antecedents of export venture performance: A theoretical model and empirical assessment. Journal of Marketing, 68(1), 90-108.

Navarro-García, A., Arenas-Gaitán, J., Rondán-Cataluña, F. J., \& Rey-Moreno, M. (2015). Global model of export performance: moderator role of export department. Journal of Business Research, 69(5), 1880-1886.

Nemkova, E., Souchon, A. L., Hughes, P., \& Micevski, M. (2015). Does improvisation help or hinder planning in determining export success? Decision theory applied to exporting. Journal of International Marketing, 23(3), 41-65.

Oliveira, J. S., Cadogan, J. W., \& Souchon, A. (2012). Level of analysis in export performance research. International Marketing Review, 29(1), 114-127.

Papadakis, V. M., \& Barwise, P. (2002). How much do CEOs and top managers matter in strategic decision-making? British Journal of Management, 13(1), 83-95.

Papadakis, V. M., Lioukas, S., \& Chambers, D. (1998). Strategic decision-making processes: the role of management and context. Strategic Management Journal, 19(2), 115-147.

Ping Jr, R. A. (1995). A parsimonious estimating technique for interaction and quadratic latent variables. Journal of Marketing Research, 32(2), 336-347.

Raven, P. V., McCullough, J. M., \& Tansuhaj, P. S. (1994). Environmental influences and decision-making uncertainty in export channels: Effects on satisfaction and performance. Journal of International Marketing, 2(3), 37-59.

Rose, G. M., \& Shoham, A. (2002). Export performance and market orientation: establishing an empirical link. Journal of Business Research, 55(3), 217-225. 
Song, M., Droge, C., Hanvanich, S., \& Calantone, R. (2005). Marketing and technology resource complementarity: an analysis of their interaction effect in two environmental contexts. Strategic Management Journal, 26(3), 259-276.

Sousa, C. M., Martínez- López, F. J., \& Coelho, F. (2008). The determinants of export performance: A review of the research in the literature between 1998 and 2005. International Journal of Management Reviews, 10(4), 343-374.

Thirkell, P. C., \& Dau, R. (1998). Export performance: success determinants for New Zealand manufacturing exporters. European Journal of Marketing, 32(9/10), 813829.

Venkatraman, N. (1989). The concept of fit in strategy research: toward verbal and statistical correspondence. Academy of Management Review, 14(3), 423-444.

Verhoef, P. C., \& Leeflang, P. S. (2009). Understanding the marketing department's influence within the firm. Journal of Marketing, 73(2), 14-37.

Vorhies, D. W., \& Morgan, N. A. (2005). Benchmarking marketing capabilities for sustainable competitive advantage. Journal of Marketing, 69(1), 80-94.

Wang, K. J., \& Lestari, Y. D. (2013). Firm competencies on market entry success: Evidence from a high-tech industry in an emerging market. Journal of Business Research, 66(12), 2444-2450.

Zeriti, A., Robson, M. J., Spyropoulou, S., \& Leonidou, C. N. (2014). Sustainable export marketing strategy fit and performance. Journal of International Marketing, 22(4), 44-66.

Zou, S., Fang, E., \& Zhao, S. (2003). The effect of export marketing capabilities on export performance: an investigation of Chinese exporters. Journal of International Marketing, 11(4), 32-55. 
Table 1. Model Fit Indicators, Correlation Matrix, and Scale Properties

\begin{tabular}{|c|c|c|c|c|c|c|c|c|}
\hline Model & $\chi^{2}$ (d.f.) & $p$-value & $\Delta \chi^{2}$ (d.f.) & RMSEA & CFI & NFI & NNFI & $\begin{array}{c}\text { Standardized } \\
\text { RMR }\end{array}$ \\
\hline Measurement model & $108.93(79)$ & .01 & - & .04 & .97 & .92 & .96 & .04 \\
\hline \multicolumn{9}{|l|}{ Structural models } \\
\hline - Model 1 (constrained model) $^{\mathbf{a}}$ & $25.35(14)$ & .03 & - & .06 & .95 & .92 & .72 & .03 \\
\hline - Model 2 (unconstrained model) & $10.57(10)$ & .39 & $14.78(4)^{\mathrm{c}}$ & .02 & 1.00 & .97 & .97 & .01 \\
\hline Measures & 1 & 2 & 3 & 4 & 5 & 6 & 7 & 8 \\
\hline 1. Export dispersion & - & & & & & & & \\
\hline 2. Export performance & $.16^{*}$ & - & & & & & & \\
\hline 3. Export customer dynamism & $.22 *$ & .11 & - & & & & & \\
\hline 4. Export technological dynamism & $.20 *$ & $.18^{*}$ & $.59 * *$ & - & & & & \\
\hline 5. Export information sharing & .07 & $.27^{* *}$ & .05 & .08 & - & & & \\
\hline 6. Interfunctional goal alignment & $.19 *$ & $.24 * *$ & -.01 & $.20^{*}$ & $.27 * *$ & - & & \\
\hline 7. Export resources & $.26^{* *}$ & $.24 *$ & .19 & $.23^{*}$ & .04 & .04 & - & \\
\hline 8. Export experience & $-.17 *$ & -.17 & -.11 & -.08 & -.06 & -.15 & .16 & - \\
\hline Mean & 17.41 & 5.56 & 3.63 & 4.02 & 4.75 & 4.91 & 19.00 & 36.32 \\
\hline Standard deviation & 8.47 & 1.78 & 1.35 & 1.39 & 1.26 & 1.05 & 32.63 & 31.09 \\
\hline Composite reliability & N.A. & .79 & .68 & .77 & .78 & .83 & N.A. & N.A. \\
\hline Average variance extracted & N.A. & .65 & .52 & .62 & .53 & .62 & N.A. & N.A. \\
\hline \multicolumn{9}{|c|}{$\begin{array}{l}\text { * Correlation is significant at the } .05 \text { level. } \\
\text { ** Correlation is significant at the } .01 \text { level. } \\
\text { a Squared multiple correlation coefficient }=.17 \\
\text { b Squared multiple correlation coefficient }=.25 \text {. } \\
\text { c Relative to Model } 1 \text { (constrained model), Model } 2 \text { exhibits a significant improvement (decrease) in chi-square. }\end{array}$} \\
\hline
\end{tabular}


Table 2: Influence of Different Functional Groups on Export Marketing Decisions ${ }^{\text {a }}$

\begin{tabular}{|c|c|c|c|c|c|c|c|}
\hline \multirow[b]{2}{*}{$\begin{array}{l}\text { Export Marketing } \\
\text { Activities }\end{array}$} & \multicolumn{6}{|c|}{ Influence of functional group } & \multirow{2}{*}{$\begin{array}{l}\text { Issue-specific } \\
\text { cross- } \\
\text { functional } \\
\text { dispersion of } \\
\text { influence b }\end{array}$} \\
\hline & $\begin{array}{l}\text { Export } \\
\text { Function }\end{array}$ & $\begin{array}{l}\text { Marketing/ } \\
\text { Sales }\end{array}$ & $\begin{array}{l}\text { Finance/ } \\
\text { Accounting }\end{array}$ & Manufacturing & $\mathrm{R} \& \mathrm{D}$ & $\begin{array}{l}\text { Sum of } \\
\text { Influence }\end{array}$ & \\
\hline $\begin{array}{l}\text { New product } \\
\text { development for } \\
\text { export markets }\end{array}$ & 24 & 32 & 8 & 13 & 23 & 100 & 50.5 \\
\hline $\begin{array}{l}\text { Export customer } \\
\text { service and support }\end{array}$ & 39 & 33 & 6 & 15 & 7 & 100 & 44.4 \\
\hline $\begin{array}{l}\text { Export pricing } \\
\text { decisions }\end{array}$ & 33 & 37 & 15 & 10 & 5 & 100 & 44.0 \\
\hline $\begin{array}{l}\text { Export distribution } \\
\text { strategy }\end{array}$ & 43 & 38 & 8 & 8 & 3 & 100 & 34.6 \\
\hline $\begin{array}{l}\text { Expansion into new } \\
\text { export markets }\end{array}$ & 39 & 46 & 7 & 3 & 5 & 100 & 33.2 \\
\hline $\begin{array}{l}\text { Export customer } \\
\text { satisfaction } \\
\text { measurement }\end{array}$ & 43 & 40 & 5 & 9 & 3 & 100 & 31.0 \\
\hline
\end{tabular}

\footnotetext{
${ }^{\mathrm{a}}$ Decisions on export marketing activities are sorted by the level of cross-functional dispersion of influence on export marketing activities; in the questionnaire, a different order was given.

$\mathrm{b}$ This measure is based on the mean of the standard deviations of influence across the five functional groups which were computed for each of the sampled firms. We subsequently rescaled it so that 0 equals minimal issue-specific cross-functional dispersion of influence and 100 equals maximal dispersion.
} 
Table 3. Path Coefficients and T-values of Constrained and Unconstrained model

\begin{tabular}{|c|c|c|c|c|c|c|}
\hline \multirow[b]{3}{*}{ Hypothesis } & \multirow[b]{3}{*}{ Coefficient } & \multicolumn{5}{|c|}{ Parameter Estimates and t-Values ${ }^{a}$} \\
\hline & & & \multicolumn{2}{|c|}{ Constrained model } & \multicolumn{2}{|c|}{ Unconstrained model } \\
\hline & & & $\begin{array}{l}\text { Standardized } \\
\text { Estimates }\end{array}$ & t-Values & $\begin{array}{l}\text { Standardized } \\
\text { Estimates }\end{array}$ & t-Values \\
\hline $\mathrm{H}_{1}$ & $\mathrm{~V}_{1}$ & Export dispersion & .02 & .25 & -.05 & -.66 \\
\hline \multirow[t]{2}{*}{$\mathrm{H}_{2}$} & $\mathrm{Y}_{2}$ & $\begin{array}{l}\text { Export dispersion x export customer } \\
\text { dynamism }\end{array}$ & - & - & .16 & 2.13 \\
\hline & $\mathrm{Y}_{3}$ & $\begin{array}{l}\text { Export dispersion } \mathrm{x} \text { export } \\
\text { technological dynamism }\end{array}$ & - & - & -.16 & -2.22 \\
\hline $\mathrm{H}_{3}$ & $\mathrm{Y}_{4}$ & $\begin{array}{l}\text { Export dispersion } \mathrm{x} \text { export information } \\
\text { sharing }\end{array}$ & - & - & -.16 & -2.11 \\
\hline $\mathrm{H}_{4}$ & $\mathrm{Y}_{5}$ & $\begin{array}{l}\text { Export dispersion } \mathrm{x} \text { interfunctional } \\
\text { goal alignment }\end{array}$ & - & - & .05 & .72 \\
\hline & $\mathrm{V}_{7}$ & Export technological dynamism & .10 & 1.16 & .07 & .77 \\
\hline & $\mathrm{Y}_{8}$ & Export information sharing & .21 & 2.57 & .24 & 3.00 \\
\hline & $\mathrm{V}_{9}$ & Interfunctional goal alignment & .09 & 1.03 & .13 & 1.43 \\
\hline & $\gamma_{10}$ & Export resources & .21 & 2.19 & .27 & 2.83 \\
\hline & $\mathrm{V}_{11}$ & Export experience & -.17 & -1.83 & -.16 & -1.77 \\
\hline
\end{tabular}


Figure 1. Conceptual Model

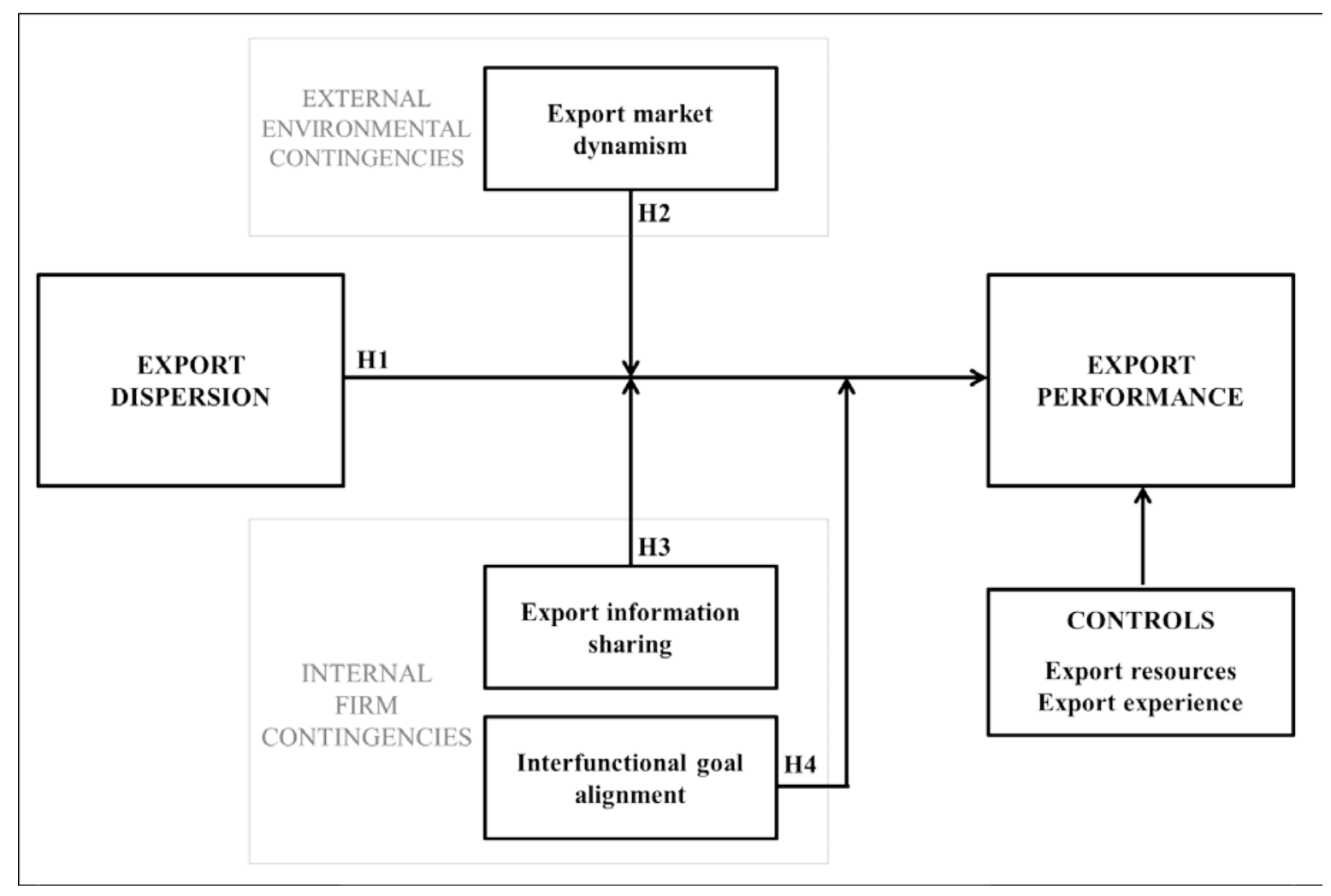


Figure 2. Export dispersion-export performance link under low and high values of moderating variables

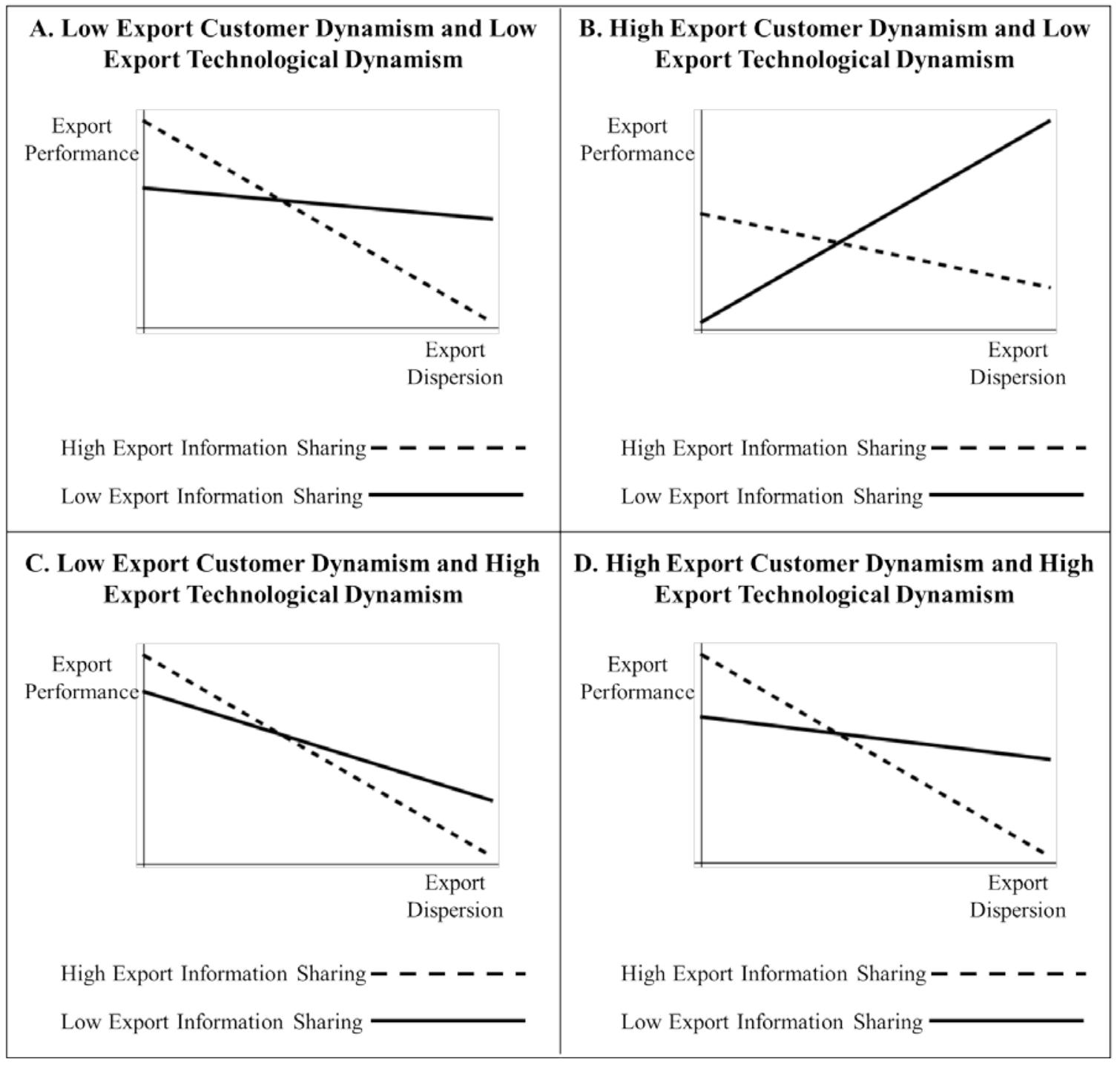




\section{Appendix - Construct Measurement}

Export Dispersion (adapted from Krohmer, Homburg, and Workman, 2002)

Measure developed by first assessing the influence of five functional groups (export function, marketing/sales, finance/accounting, manufacturing, and R\&D) over eight strategic decisions on export marketing activities by using a 100-point constant-sum scale: (1) export pricing decisions; (2) decisions on new product development for export markets; (3) export customer satisfaction improvement decisions; (4) decisions on export customer service and support; (5) export customer satisfaction measurement decisions; (6) export distribution strategy decisions; (7) decisions concerning expansion into new export markets, and; (8) export market advertising decisions. Standard deviations of influence scores were then computed for each decision. In the extreme case of identical influence across all functional groups regarding a certain decision, the standard deviation of the corresponding influence score is equal to zero, which indicates maximum dispersion of influence across functional areas regarding the decision. The mean value of across the eight standard deviations was then calculated and the resulting values multiplied by -1 . Finally, we adjusted the scores obtained to create our final dispersion index, where 0 and 44.72 correspond to minimum and maximum of export dispersion, respectively.

Export Profit Performance (adapted from Cadogan et al., 2005)

1. Export Profitability over past 3 years (1 = "very dissatisfied"; 10 = "very satisfied").

2. Degree of profitability of exporting over last financial year ( 1 = "very unprofitable"; $10=$ "very profitable").

Export customer dynamism (adapted from Jaworski and Kohli, 1993)

( 1 = "not at all"; 7 = "to an extreme extent")

In our export markets:

1. New customers tend to have product-related needs that are different from those of our existing customers.

2. Our export customers tend to look for new products all the time.

Export technological dynamism (adapted from Jaworski and Kohli, 1993)

(1 = "not at all"; 7 = "to an extreme extent")

In our export markets:

1. The technology in our industry is changing rapidly.

2. A large number of new product ideas have been made possible through technological breakthroughs in our industry.

Export information sharing (Cadogan et al., 2001)

(1 = "very strongly disagree"; 7 = "very strongly agree")

1. Too much information concerning our export competitors is discarded before it reaches decision makers (reverse coded).

2. Information which can influence the way we serve our export customers takes forever to reach export personnel (reverse coded).

3. Important information about our export customers is often 'lost in the system' (reverse coded).

4. Important information concerning export market trends (regulation, technology) is often discarded as it makes its way along the communication chain (reverse coded).

Interfunctional goal alignment (adapted from Cadogan, Diamantopoulos, and de Mortanges, 1999)

1. Functional areas in this company pull together in the same direction.

2. The activities of our business functions (e.g. exports, marketing/sales, manufacturing, R\&D, finance/accounting, etc.) are integrated in pursuing a common goal.

3. We resolve issues and conflicts through communication and group problem-solving.

Export resources (adapted from Thirkell and Dau, 1998)

Number of full-time employees directly involved with export matters.

Export Experience (Bijmolt and Zwart, 1994)

Number of years the firm has been exporting. 